\title{
FORCED TAX COLLECTION PROCEEDINGS IN BRAZIL: AN OVERVIEW OF FEDERAL LAW NO. 6,830
}

Bruno Fernandes Dias

Prospective graduand 2014 of International Law at University of the State of Rio de Janeiro. Public Attorney at the AttorneyGeneral's Office of the State of Rio de Janeiro. Lawyer.

\begin{abstract}
In Brazil, despite there being specific legislation regulating forced tax collection proceedings, these are still largely influenced by case law of national courts. We are now living in the third decade of Federal Law No. 6,830, promulgated in 1980, which aimed to guarantee greater privileges to the treasury in the course of the debt collection saga. However, the many loopholes and lacunae gaping throughout the text have left all stakeholders - government, taxpayers and judges somewhat exasperated. Part II of this Paper analyzes the main features of forced tax collection proceedings: registration of the tax liability, presumption of liquidity and certainty; definition of "responsible" persons in terms of the law; collateralization and challenges to the debt; and the tax liability vis-à-vis other debts. A brief look is given to other pieces of procedural legislation related to tax disputes, most importantly the suits for a writ of mandamus; actions for restoration of undue payments, and actions for annulment. Finally, summaries of case law of the Superior Court of Justice are considered. These form an essential part of Brazilian sources of case law, most especially in tax proceedings.
\end{abstract}

Keywords: Forced tax collection - overdue tax liability - Federal Law No. 6,830.

\section{INTRODUCTION}

The aim of this study is to briefly describe the main mechanism of debt collection Brazilian public entities employ before local courts, in actions filed against indebted persons and companies. On the one hand we find, in Brazil, specific legislation regulating relevant aspects of the judicial proceedings of this kind. On the other hand, developing in thorough detail these juridical norms, national courts have contributed 
greatly to the definition of rules which forced tax collections should abide by.

However, the practical reality that surrounds these collections seems to be much richer and more interesting than its legal regulation suggests. Indeed, few things in Brazilian law have so bad a reputation as forced tax collections. From all angles they receive criticisms, feed angers and cause desperation. The Judiciary blames such actions as the main cause of inundation of files on its shelves. The administrative body which controls most of the activities of Brazilian courts - the National Council of Justice ${ }^{1}$ - has sought to make feasible some alternative tools of debt collection, aiming to reduce the amount of work courts need to coordinate when handling pending forced tax collections. In this vein, back in 2010, the Council decided as follows in Petition of Provision No. 200910000045376: it considered valid a private protest of certificates of overdue tax liability - locally known as certidões de divida ativa ${ }^{2}$-, and in doing so established that the debtor could be subjected to indirect means of collection and that he should bear the expenses of said proceeding ${ }^{3}{ }^{4}$. Although important, this provision did little in trying to achieve its aim: data from the Council still shows that a total of 29.2 million forced tax collections are currently pending throughout the country. This amount corresponds to an impressive 32\% of the total of 92 million cases standing before the Judiciary ${ }^{5}$.

Civil society as well sees itself as a victim to this spate. Many claim that this type of tax collection violates various guarantees the Constitution asserts to Brazilian persons and companies, specially the principle of due process of law and of adversary proceedings. More generally, they complain of the expenses involved in keeping up a

1 Brazil. Constitution (1988). Article 103-B, paragraph 4.

2 Throughout this paper, for didactic purposes, the expression "tax liability" will be used in place of the Portuguese expression "dívida ativa". It must be noted, however, that Article 2 of Law No. 6,830 stipulates that within the concept of divida ativa one also finds debts which are not properly related to taxes, but instead are derived from other kinds of public law legislations. Except when expressly referred, this distinction is not relevant to the aspects of forced tax collection proceedings this paper aims at describing.

3 DECISÃO do CNJ contribui para a redução do número de execuções fiscais. Website of the National Council of Justice, 13 Dez. 2013. Available at: <http://www.cnj.jus.br/noticias/ cnj/27161-decisao-do-cnj-contribui-para-a-reducao-do-numero-de-execucoes-fiscais $>$. Access on: 29 Jun. 2014.

4 Later, in 2012, Federal Law No. 12,767 expressly gave the government the right to use this indirect means of collecting debt, whereby data of debtor is sent to credit protection firms, thus allowing other corporations to asses the debtor's credit history and refrain from doing business with him.

5 EM pauta a desjudicialização da execução fiscal. Website of the National Council of Justice, 30 Jan. 2014. Available at: <http://www.cnj.jus.br/noticias/cnj/27472-em-pauta-adesjudicializacao-da-execucao-fiscal $>$. Access on: 29 Jun. 2014. 
proper structure to hold such a substantial amount of disputes ${ }^{6}$.

Disputes in regard to federal taxes take up a central position at this stage - in this general category one observes a clear predominance of cases the government files against companies, which are twelve times more frequent than those cases companies file against the government. Data has shown that the legal expenses of pending cases override the costs related to lawyers' fees. Currently, out of those cases Brazilian companies litigate before national courts, tax disputes are the ones which make up the greater financial input; whilst consumer disputes represent a greater number of processes. Companies bear, for instance, the costs involved in posting an undertaking in court to judicially discuss charges made against them by the fiscal administration. Other factors commonly featuring in such cases are the negative economic repercussions which crop up when financial assets are inadvertently frozen (in the form of bank deposits, for instance) at an amount greater then that charged by the government. Even when the charges are considered to lack legal foundation, companies also need to spend money on accountancy services, and must make provisions for possible losses. ${ }^{7}$

The Executive also faces a dilemma. Billions of reais ${ }^{8}$ are currently registered as overdue tax liabilities, but the tools to collect them prove to be somewhat artificial or purely inefficient. A study made by the Institute for Research in Applied Economics, in 2011, has shown that every forced tax collection lasts on average eight years and two months. According to this research, the summons of the debtor alone that is the primary act by which the defendant forms part of the process - takes up to five years. Furthermore, the seizure of any asset takes yet another year. In other terms, it takes up to six years just to locate the assets of the defaulting taxpayer. Against this background, the research has tried to implement some degree of rationalization in the criteria one uses to determine the minimum amount above which it becomes economically recommendable for the govern to try to collect the debt. ${ }^{9}$

6 GASTO de empresas com processos chega a R\$ 110 bi. Valor Econômico, São Paulo. 4 Feb. 2014. Available at: <http://www.valor.com.br/legislacao/3418112/gasto-de-empresas-comprocessos-chega-r-110-bi\#ixzz34O1tYy8w>. Access on: 18 Jun. 2014.

7 See: note 6.

8 It is estimated that the federal government has more than $\mathrm{R} \$ 500$ billions reais to collect as tax liabilities. See: DÍVIDA ativa da União chega a R \$557,5 bilhões, valor comparável ao PAC 1. Contas Abertas. 14 May. 2012. Available at: <http://www.contasabertas.com.br/website/ arquivos/1148>. Access on: 19 Jun. 2014.

9 The rationale to calculate this amount makes use of a break even analysis. "Taking in consideration the total cost of a tax foreclosure and the probability of successfully collecting the debt, one may state that the break even point - the point in which it becomes economically justifiable to proceed with a tax foreclosure is $\mathrm{R} \$ 21.731,45$ reais. That is to say: it is unlikely that the federal government collects more money than it spends in tax foreclosures whose total debt is less than $\mathrm{R} \$ 21.731,45$ reais" See: NOTA Técnica. Custo e tempo do processo 
In the midst of a significant quantity of cases, one collateral effect is the hindrance in the development of some proceedings, which individually add to very high amounts and which oftentimes originate from solvent companies. The reaction to this sort of inefficiency has so far been feeble. Such a conjuncture has made the Brazilian Central Bank create mechanisms and structures aimed solely and specifically to litigate against companies whose debts totalled to more than seven million reais. The origin of the said arrears varies substantially. Perpetrated irregularities in exchange operations, and other forms of operations committed by residents living abroad, but having repercussions in Brazil, could trigger the performance of the Bank and the consequent application of fines. What draws our attention at this point are the particular strategies which have been adopted by the Bank in order to enhance debt collection. Perhaps the main one of those, rather paradoxically, is an alternative to the usual forced tax collection, and not an improvement of this remedy: the protest of certificates of overdue tax liabilities, which was made viable, without expenses for the Bank, by means of the agreement with the Institute of Studies for the Protest of Titles in Brazil ${ }^{10}$.

The contribution of the Legislative Branch, in its turn, seems simply to reaffirm that forced tax collections are too complex to be solved. Currently, parliamentary discussion is ongoing regarding Bill No. 5,090/2009, whose purpose, amongst other things, is to create a scheme of "Administrative Forced tax collection"11. As the new scheme should empower tax authorities to seize debtor's assets, criticism has been raised regarding the constitutionality of this measure, mostly in the light of the principle that no threat or violation to rights could be excluded from the consideration of the Judiciary ${ }^{12}$. Given the fact that no other legislation of relevance seems to be in the making, however, the legal developments which have taken place in this matter, as will be seen throughout this study, almost always emanate from courts.

\section{THE BASIC STRUCTURE OF FEDERAL LAW NO. 6,830}

\section{The first legal statute to mention forced tax collections in Brazil}

de execução fiscal promovido pela Procuradoria-Geral da Fazenda Nacional. Nov. 2011. Available at: $<$ http://www.ipea.gov.br/agencia/images/stories/PDFs/nota tecnica/111230 notatecnicadiest1.pdf.> Access on: 23 Jun. 2014. Freely translated.

10 BC apertará o cerco a grandes devedores. Valor Econômico. São Paulo, 27 Apr. 2014. Available at $\quad<$ http://www.valor.com.br/financas/3507244/bc-apertara-cerco-grandesdevedores\#ixzz34NzMYotQ>. Access on: 18 Jun. 2014].

11 Brazil. Chamber of Deputies. Bill no 5080/2009. Available at: < http:/www.camara.gov.br/ proposicoesWeb/fichadetramitacao?idProposicao=431260>. Access on: 1 Jul. 2014.

12 Brazil. Constitution (1988). Article 5, XXXV. 
was Law-Decree No. 960, of $17^{\text {th }}$ December 1938, under the auspices of the Constitution of $1934^{13}$. In 1973, with the issuing of the Code of Civil Procedure of 1973, the norms of procedural law provided by means of Law-Decree No. 960/38 were revoked, following the understanding expressed by the Supreme Federal Court ${ }^{14}$. For this reason, forced tax collections were no longer filed under a specific set of rules.

This landscape only came to change with the issuing of Law No. 6,830 , in 1980. Recital No. 223 highlighted that the objectives aimed by the model proposed therein consisted in guaranteeing greater privileges to the treasury in seeking satisfaction of its credits. One hoped it would thus facilitate and simplify the collection of tax liabilities ${ }^{15}$.

This law is composed of 42 articles. The main issues it concerns are the following: concept of Tax Liability (Article 2); legal provision that the amounts charged are presumably correct (Article 3); list of persons who may be charged by means of forced tax collections (Article 4); formal requirements that the proceedings of forced tax collections should abide by (Article 6$)^{16}$; acts and effects derived from the moment the Judiciary processes the case (Article 7) ${ }^{17}$; admitted forms of collateralizing the debt so that the debtor may challenge the charges (Article 9); debtor's assets which may be seized (Article 11); proceedings to be followed when the debtor intends to challenge the debt (Articles 16 to 20); rules about the use of seized assets (Articles 21 to 24); legal regime of tax liabilities compared with other sorts of debts a person or a company may have (Article 38); applicable rules when the debtor or his assets are not found (Article 40).

\section{1. The Tax Liability Concept}

This is a fundamental notion to this study. The legal definition of Tax Liability represents, to a certain extent, the intermediary point between the activities developed by means of fiscal agents, when

13 NASCIMENTO, Márgara Bezerra. Execução fiscal: administrativa ou judicial?. Âmbito Jurídico, May 2013. Available at: http://ambitojuridico.com.br/site/?n_link=revista_artigos_ leitura\&artigo_id=13327\&revista_caderno=2 6. Access on: 29 Jun. 2014.

14 Brazil. Supreme Federal Court. Recurso Extraordinário $n^{\circ}$ 94.071/SP. Minister Aldir Passarinho, 26/04/1984. DJ 24-08-1984, pp.13479.

15 MARTINS, Vinícius Camargos. A nova execução fiscal. Jus Navigandi, Feb. 2010. Available at: <http://jus.com.br/artigos/14350/a-nova-execucao-fiscal > Access on 29 June. 2014.

16 Procedural aspects and documents which must form part of tax liability foreclosures are enumerated in Article 6 of Law No. 6,830. This provision clarifies the judicial and litigious features of forced tax collections.

17 The logic of the relevant procedural steps is to summon the debtor and then focus on the measures necessary to find his assets. After being notified, he is granted 5 days either to pay the debt or pledge an asset as security. In default of such the debtor's assets may be levied for execution. 
these monitor persons and companies and check if all dues were paid according to law; and the activities of those professionals which are also included in the structure of the tax administration, but which, as public lawyers, exercise privately the judicial collection of debts which the taxpayers failed to spontaneously pay off. The purpose of registering a debt as an overdue tax liability is to improve collection, by means of unilaterally creating an enforceable remedy without any kind of written intervention of the debtor. ${ }^{18}$

It should be noted that apart from Federal Law No. 6,830/80, rules emanating from other laws also play an important role when it comes to forced tax collection proceedings. For example, the Federal Constitution outlines basic rules in regards to charges which public entities are authorised to pursue, apart from other rules of an authoritative kind which result in the charge of pecuniary values. ${ }^{19}$ Thus, Article 153 provides that the federal government may charge, amongst others, tax upon the import of foreign goods and upon income. In turn, Article 155 authorizes States to charge tax upon operations of circulation of goods. Other charges are also regulated by the Constitution. Such is the case of the rule for environmental protection entrenched in Article 225 paragraph 3, for fines charged against persons and companies in violation of environmental rules may be registered as an overdue liability and thus follow a proceeding similar to that of a forced tax collection.

Both the treasury as well as taxpayers are subject to yet another general set of rules aimed at organizing the performance itself of tax authorities at the moment of monitoring persons and companies, and eventually formalizing administrative proceedings of collection. One also has in mind, here, a reality which takes place prior to the moment of registering the debt as an overdue tax liability: in practical terms, what takes place is an administrative act against which the taxpayer may still as yet defend himself and which the tax administration, by means of its bodies and administrative courts, may still come to review. ${ }^{20}$ Article 142 of the National Tax Code enshrines the basic rule in the matter. It reads that the act of assessment is what gives rise to the proceeding of collecting taxes in regards to which the taxpayer is default. Upon commencement of this proceeding, it often happens that the charges are

18 CARVALHO, Paulo de Barros. Curso de Direito Tributário. São Paulo, 20a ed. rev. São Paulo: Saraiva, 2008. Pág. 578.

19 Scholars give prominence to the role of the Constitution in legitimizing legislation passed by the federal government, as well as by the states and the municipalities. The Constitution objectively describes facts which may put by the ordinary legislators (federal, state or municipal) as abstract taxable events. See: CARRAZZA Roque Antônio, ICMS, $12^{\text {th }}$ ed. São Paulo: Malheiros, 2007, pp. 34-35.

20 Brazil. National Tax Code. Article 201. 
overruled by the upper bodies of the tax administration. It is only upon termination of this proceeding, and when its conclusion has shown that the allegations of the taxpayer shall not be accepted (or when the taxpayer has not even presented any challenge) that the concept of Tax Liability starts to crop up. Article 201 of the National Tax Code refers to these procedural dynamics, which usually encompasses the hearing of appeals by panels composed solely of tax collectors and, at a final level, by panels composed both by tax collectors and private sectorindicated experts, collectively named Council of Taxpayers.

After being registered as an overdue tax liability, tax charges go on to be influenced with a greater visibility by Federal Law 6,830. This law intends to regulate the forms through which the tax administration will attempt to collect its debts, a goal that, in Brazil, requires the intervention of the Judiciary and the technical work of lawyers, both taxpayers' and government's.

Meanwhile we may also see a more general dimension within the concept of tax liability, which is of a budgetary kind. As a whole, debts to be collected aggregate substantial amounts which go into the calculation of what the government is supposed to receive and invest ${ }^{21}$. Hence, Article 2 of Law 6,830 makes express reference to Federal Law No. 4,320 of 1964, the national statute for public finances. In Article 39 paragraph 2 of Federal Law No. 4,320, a distinction is made between Tax Liability (Dívida Ativa Tributária) and Non-Tax Liability (Dívida Ativa Não Tributária), both of which aim to take in not only all those situations which concern pecuniary obligations which affect the national budget, but also all those aspects which alter the individual amount of each debt in a concrete manner, such as the inflation adjustment interests, fines, etc. ${ }^{22}$

\section{2. Registration of Tax Liability}

The formal act of registering tax liabilities is intended to be subjected to an administrative legality control (Article 2, paragraph 3 of Federal Law No 6,830). There will hardly be any uniformity in the rules or parameters utilized in such activity by the innumerable administrative sectors of the country, in the various federal levels. Generally, this task is run by automated computer programs, developed and sold by specialised public or private companies, and designed to ensure acceptable standards of information. The depth of the juridical and technical analysis may change, on another hand, in accordance with

21 Because it applies to the federal, state and municipal governments (article 2), Law No. 6,830 is formally federal, but has a national nature. Therefore, in all of these three government levels, the basic rules for tax foreclosures are the same.

22 Brazil. Federal Law No. 6,830. Article 2, paragraph 2. 
the personal inclinations of the responsible agents; with the amounts in question; and with the complexity which oftentimes characterize the necessary stages of administrative discussion between the assessment of the debt and the administrative final decision, usually separated by an interval of some years.

\section{3. The presumption of certainty and liquidity of Tax Liability}

This feature of debts registered as overdue tax liabilities originates from various premises of the legal regime of public law which regulates tax administration, and which in Brazil is characterised by a strong predominance of the public interest over the private sphere. Article 3, single paragraph, of Federal Law No. 6,830, establishes a relative nature to the presumption of certainty (that is, that the charges are in accordance with the relevant rules), and liquidity, (that is, that the value of the debt, such as that informed by the administrative authority, is correct $)^{23}$. Considering that such presumption is relative, it "may be refuted by an unequivocal proof". The scope of this principle, nevertheless, does not limit itself to the need of the unequivocal proof, and argumentatively legitimises the need of collateralizing the debt so that the debtor may challenge the charges (Article 9).

\section{4. Debtors}

Article 4 of Federal Law No. 6,830 lists the persons against whom forced tax collections may be filed. These are: debtor; successors; surety; the estate; bankruptcy estate; person responsible, in terms of law, for debts, tax-related or otherwise, of natural or juridical persons of private law; any sort of successors.

Indeed, it is fairly common that forced tax collections be filed against third parties, other than the original debtor. Under the general category of persons the law considers to be "responsible", one often finds members of companies having chronicle financial problems (Article 135, III, of the National Tax Code). This Article lays out a rule stating that directors, managers or legal representatives of companies may become personally liable for debts resulting from acts of abuse of power, acts in violation of law, or in violation of the acts of organization or acts of incorporation.

Many controversies have arisen in this respect and one finds in case law the circumstances in which the lifting of the corporate veil is considered to be acceptable - to the detriment, some would argue, of

23 CAIS, Cleide Previtalli. O Processo Tributário. $5^{\text {th }}$ ed. rev. e ampl. São Paulo: Ed. Revista dos Tribunais, 2007, pp. 600. 
entrepreneurship in the country ${ }^{24}$. In this regard, as a matter of fact, private law, contract-related, disputes prove to be treated differently from public law, tax-related cases. The Superior Court of Justice has ruled that when it concerns private interests only, lifting the corporate veil requires proof that the member purposely exhausted the company's estate so as to circumvent the company's debts. On the other hand, in tax cases, provided that the requisites to Article 135 of the National Tax Code are satisfied, disregarding the corporate entity is possible. Either way, merely failing to settle a debt does not suffice for the corporate veil to be lifted.

\section{5. Collateralizing and challenging the debt}

Generally, in the most relevant cases, the debtor collateralizes and challenges the debt. Of course, this turns the situation into one which resembles a normal action suit where an administrative act is brought before the Judiciary for review. Collateralization rules are provided by Article 9 of Federal Law No. 6,830, which brings forth some possibilities to the defendant, such as: placing a deposit in cash to a bank account managed by the court; offering a bank surety; even yet, offering property to be levied upon, such as bonds; precious stones and metals; real estate; ships and aircrafts; vehicles, movables and livestock; and rights and actions (Article 11).

Controversies over collateralization may arise, for instance, if taxpayers wish to secure the debt with a particular object, and the public attorney, taking into consideration the existence of a more liquid or valuable object, purports that the best option should be that other one. It often happens that the parties simply cannot come to an understanding regarding the value of the object in question. Trivialities such as the charging of interest, or the period of validity, also lead to bank sureties issued by prominent institutions end up being rejected.

Throughout the forced tax collection proceeding, whilst parties might still be discussing collateral issues, the judge may rule on a matter and thus give rise to appeals which may be heard on different panels and several courts. There also exists a provision for the debtor to pay only a part of the debt and collateralize for the remainder (Article 9, paragraph 6).

Discussions are often raised on issues regarding collateralization $v i s-\grave{a}$-vis the need of certificates of suspended tax liabilities. Such a certificate mostly affects the activities of companies that have public contracts with the government, and/or lines of credit with bank

24 STJ protege bem de sócio de empresa irregular. Valor Econômico, São Paulo. 21 Mar. 2014. Available at: <http://www.valor.com.br/legislacao/3488368/stj-protege-bem-de-sociode-empresa-irregular\#ixzz34Nzh MmnE>. Accessed on: 19 Jun. 2014. 
institutions interested in verifying the financial situation of its borrowers. Should this certificate be required as proof of good standing and tax clearance, the company's interest in collateralizing often supersedes its interest in challenging the merits of the charges. This may bring about the situation where the collateral offered is fit and proper for the acquisition of the certificate, but not sufficient to cause the cessation of the foreclosure acts. The principal provisions which consider this type of document are Article 205 and 206 of the National Tax Code: the first regulating the so-called "negative certificates", through which one is informed that the taxpayer has no debt; the second, regulating the situations in which the taxpayer, despite having debts, adopted actions so as to collateralize its off-payment.

In extreme cases, proof of good standing and tax clearance may be required not only for secondary aspects of the activities of the company, but also in order to obtain a permit to do business. This is a frequent scenario in the cigarette industry, by means of Law Decree No. 1,593/1977. Article 1, paragraph 2, of the Decree provides that the concession of a special permit for the manufacturing of cigarettes depends on tax compliance. However, this rule is not only applicable to the companies themselves, but has a wider scope. It aims at avoiding that those involved in the cigarette industry abuse the corporate veil to circumvent tax laws. Thus, this Law Decree also requires that tax payment compliance is proven by "members (natural persons), directors, managers, administrators and proxies", and also "corporations controlling the [company], as well as their respective members, directors, managers, administrators and proxies".

In terms of Article 2(II) of the Law-Decree there also operates a rigid system of cancellation of the special permit. In such a case, the administrative sanction is exercised prior to any forced tax collection, or even any such possible circumstance where the issue of the company's standing and tax clearance is considered under the auspices of Articles 205 and 206 of the National Tax Code. In accordance with this provision, the special permit could be cancelled at any time by the conceding authority, if, following its concession, there exists a failure to discharge a debt or actually to comply with any ancillary tax obligation. ${ }^{25}$

Where the recovery of a debt should reach the stage of a forced tax collection, nevertheless, the debtor could still opt to present his defence on the merit on issue. For this reason, the law establishes a 30-day term spanning from the moment in which an undertaking

25 Case-law emanating from the Supreme Federal Court has been favorable to the government in cases where the constitutionality of Law-Decree No. 1,593 has been challenged. See Supreme Federal Court. Recurso Extraordinário n ${ }^{\circ}$ 550769. Minister JOAQUIM BARBOSA. DJe 3 Apr. 2014. See also: Supreme Federal Court. Ação Direta de Inconstitucionalidade no 3.952 , still pending of a final judgement. 
is posted (Article 16). The scope of such challenge is wide, but not unrestrained, since no eventual compensation ${ }^{26}$ or counterclaim ${ }^{27}$ could be examined (Article 16, paragraph 3). All matters that are relevant to the defendant's arguments could come to be debated in this action, including allegations which might have already been raised before the administrative bodies. Actually, the structure of public law unfolds a gulf in the type of allegations debtors make in judicial and administrative courts. Traditionally, the latter do not recognise that the law, which served as a basis for action made by the fiscal agent, may be declared unconstitutional.

Arguments that are predominantly legal in nature, as opposed to simple factual statements, might be downright endless. Apart from those cases where the legal issue is well-defined, but in the case at hand has been wrongly applied by the tax authority, or misunderstood by the taxpayer, there exist other cases where there simply is no consensus regarding the meaning of the law. From a federal viewpoint, some controversies ongoing in Brazil are: determination of a rule regarding the validity of increase of rate of import ${ }^{28}$ and export ${ }^{29}$ tax; possibility of imposing taxes upon profits made abroad by corporations controlled by Brazilian companies ${ }^{30}$; possibility of equating a product imported from a country signatory to the Mercosul to a national product, in the tax regime regarding industrialized products ${ }^{31}$; possibility of charging taxes upon financial operations when applicable, in theory, a commercial protection treaty between countries ${ }^{32}$; necessity, in order to obtain exemption of the tax upon rural property, for annotations in the registry of deeds of the areas of the estate in which use is restricted by environmental reasons ${ }^{33}$.

\section{6. Tax liability vis-à-vis other debts}

The general precepts regarding the relation of tax liabilities and

26 Brazil. National Tax Code.Article 170.

27 Brazil. Code of Civil Procedure. Article 315.

28 Brazil. Superior Court of Justice. Recurso Especial n 191.426/CE, Minister HUMBERTO GOMES DE BARROS, DJ 27 Sep. 1999, p. 48.

29 Brazil. Superior Court of Justice Recurso Especial n 964151/PR, Minister JOSÉ DELGADO, DJe 21 May. 2008.

30 Brazil. Superior Court of Justice Recurso Especial n $1325709 /$ RJ, Minister NAPOLEÃO NUNES MAIA FILHO, DJe 20 May. 2014.

31 Brazil. Superior Court of Justice Recurso Especial no 1205393/RJ, Minister MAURO CAMPBELL MARQUES, DJe 16 Apr. 2013.

32 Brazil. Superior Court of Justice Recurso Especial n 228.324/RS, Minister JOÃO OTÁVIO DE NORONHA,DJ 01 Jul. 2005, p. 458.

33 Brazil. Superior Court of Justice EDcl no AgRg no Recurso Especial n ${ }^{\circ}$ 1315220/MG, Minister ARNALDO ESTEVES LIMA, DJe 08 May. 2014. 
other liabilities of the debtor are laid down in Article 29 of Federal Law No. 6,830. This provision determines that forced tax collections are not hindered by bankruptcy proceedings. This means that the forced tax collection may be decided, and may proceed as usual, even when there coexist other recovery proceedings against the insolvent debtor and when his estate is already known to be insufficient to satisfy all due debts. Article 29 certainly is not the only rule to consider this issue, and at some degrees, this rule is far from being absolute. However, as a rule, the right of public entities to collect debts may only be limited when another public entity also has debts to recover from that person or company. Sharing schemes will vary according to the federal levels involved, and, rather importantly, Article 31 provides that in insolvency proceedings the disposal of the debtor's assets may only be allowed if there is proof of tax clearance or with the consent of the treasury.

In Article 186 of the National Tax Code one notes important details to this structure. Amended in 2005, Article 186 establishes that tax liabilities take priority over any other type of debt, regardless of its nature or of the time it was assessed, except for the labor related debts. Specifically in the case of insolvency, the legislator chose to place the tax credits in the third position of preference. They follow those originated from labor legislation, with a limitation to hundred-and-fifty minimum wages per creditor and those derived from work accidents. Secondly one finds debts with security interest, the limit being that of the asset (Article 83, I and II of Federal Law No. 11,101 of 2005).

\section{II.7. Other procedural legislation related to tax disputes}

The scope of application of Federal Law 6,830, however wide, is not exhaustive in regards to the procedural forms in which tax disputes arise and are settled in Brazil. Both taxpayers and the government may make use of remedies provided by other sorts of legislation. From the government side, Federal Law No. 8,397, of 1992, provides for provisional remedies to be filed as a way of anticipating and speeding up stages of a regular forced tax collection. The law is aimed at debtors fitting the provision of Article 2, that is to say, debtors who right from the start will be perceived as not being capable of easily satisfying their debt. Article 2 brings forth examples such as that of a debtor who "contracts or attempts to contract debts which endanger the liquidity of his estate"; or which "transfers or attempts to transfer his estate to third persons". The provisional measures envisioned by Federal Law No. 8,397 ensure the inalienability of the debtor's assets, limited to the amount of the debt.

Article 38 of Federal Law No. 6,830, on the other hand, also mentions other remedies taxpayers may drawn on when challenging tax 
charges: suit for a writ of mandamus; restoration of undue payments; and action for annulment.

By means of Article 5, LXIX, of the Federal Constitution, and Federal Law No. 12,106, of 2009, suits for a writ of mandamus are highly used against illegalities or abuses carried out (or about to be carried) by public authorities ${ }^{34}$. One of its advantages is the rapidity in which it is heard in courts. Apart from this law referring to tax issues only to create a restriction - the impossibility of tax set-offs be granted by provisional remedies, as laid out in Article 7, paragraph $2-$, suits for a writ of mandamus are routinely used by taxpayer's lawyers to annul (or avoid the practice of) administrative charges. The basic premise here is that the documentary evidence be unequivocal and thus be filed since the beginning, an entirely different scheme than that which rules ordinary suits. Several different subjects are brought to courts by means of these suits, for example: possibility of Brazilian companies sending money abroad, without having to withhold income tax, in operations related to payments made to commercial partners that had allowed the use of telephone lines outside the national territory, having in view the discrepancy between internal legislation and the International Telecommunication Union ${ }^{35}$; possibility of clearing goods through customs without paying tax on the circulation of goods, considering the debate over the levy of the tax on medical devices imported under a lease with option to purchase ${ }^{36}$; possibility of importing cod without having to pay tax on the circulation of goods, in view of the exemption granted in the ambit of the GATT ${ }^{37}$; the legality of the special tax regime of drawback ${ }^{38}$.

An action for restoration of undue payments, in turn, takes place when taxpayers wish to challenge the charges after having paid what the tax authorities deemed to be due. In Article 165 of National Tax Code we find the basic circumstances which justify this type of action. It is worth pointing out, for instance: an error in identifying the debtor; in determining the applicable rate; in calculating the sum of the debt; or in elaborating or checking any document relative to the payment; reform, annulment, revocation or termination of the decision in which

34 MEIRELLES, Hely Lopes. Mandado de Segurança. 30a ed. São Paulo: Malheiros, 2007. Págs. 25-26.

35 Brazil. Superior Court of Justice AgRg no Recurso Especial n ${ }^{\circ} 1104543 / R J$,. Minister BENEDITO GONÇALVES, PRIMEIRA TURMA, julgado em 04/05/2010, DJe 10 May. 2010.

36 Brazil. Superior Court of Justice AgRg no Recurso Especial no 1205993/SP, Minister BENEDITO GONÇALVES, PRIMEIRA TURMA, julgado em 26/10/2010, DJe 05 Nov. 2010. 37 Brazil. Superior Court of Justice AgRg no Ag no Recurso Especial no 551.068/RJ, Minister HUMBERTO MARTINS, SEGUNDA TURMA, julgado em 23/09/2008, DJe 23 Oct. 2008. 38 Brazil. Superior Court of Justice AgRg no Mandado de Segurança $n^{\circ}$ 11.084/DF, Minister JOSÉ DELGADO, PRIMEIRA SEÇÃO, julgado em 26/04/2006, DJ 22 May. 2006, p. 137 
the charges were considered to be correct.

Taxpayers may also make use of an action for annulment. Its scope - that of attempting to somehow avoid tax charges - is essentially the same as all other remedies. Likewise, allegations taxpayers may present by means of an action for annulment resemble those taxpayers would use in the abovementioned remedies. Nonetheless, amongst advantages and disadvantages, actions for annulment do not require that the taxpayer's claim be based on a liquid and certain right, as happens with a suit for the writ of mandamus. Indeed, it is quite common that the merits of the taxpayer's challenge will only be aptly demonstrated following a phase of auditing of documents or of the company's operations. Another inducement for the use of this remedy is that it does not require that the debtor should post an undertaking before he challenges the charges. It is a disadvantage, however, that by simply filing this remedy the debtor should fail to put a stop to any forced tax collection that might have been filed against him.

Finally, one should refer to a remedy commonly named by Brazilian practitioners as "exceção de pré-executividade". This remedy originated from scholarly writings and case-law ${ }^{39}$ rather than from a statutory basis. It was conceived, both in tax-related cases as well as in private law-related disputes, to allow debtors to promptly present claims relating to a general sense of public order. In practical terms, at any given point of a forced tax collection a debtor may use this remedy so as to seek the annulment of the tax liability, provided that he produces all documentary evidence to support his allegations. Indeed, no further fact-finding would be permitted, otherwise the action would be dismissed by the court. However, since debtors are not required to post an undertaking when using this remedy, the scope of the annulment is rather narrow and might not refer to general challenges against the charges. An account of issues which might come to the fore in a exceção de pré-executividade would include, for instance: absolute lack of jurisdiction; limitation to the collection of the debt; irregularity in the service of summons; previous payment or offset of the debt. ${ }^{40}$

\section{SUMMARIES OF CASE LAW OF THE SUPERIOR COURT OF JUSTICE}

"Entries in the annals of dominating jurisprudence" 41 of the

39 CAIS, Cleide Previtalli. O Processo Tributário. $5^{\text {th }}$ ed. rev. e ampl. São Paulo: Ed. Revista dos Tribunais, 2007, pp. 694.

40 CAIS, Cleide Previtalli. O Processo Tributário. $5^{\text {th }}$ ed. rev. e ampl. São Paulo: Ed. Revista dos Tribunais, 2007, pp. 696-703.

41 Being a literal translation of "verbete da súmula de jurisprudência dominante", this expression may be aptly replaced by "summary of case law". One should note that that is not a reference 
Superior Court of Justice, hereinafter referred to as "summaries of case law", represent the understanding of the Court regarding various topics of federal legislation. According to the Constitution, this Court has jurisdiction to hear appeals originating from second instance courts throughout the country; and in this capacity it plays a harmonizing role in the application of federal legislation (Article 105, III). In most cases, this affects local courts in an advisory, rather than a mandatory manner. Thus, local judges may decide cases - and they indeed often end up doing so - contrary to what was determined in a summary of case law. However, procedural legislation contains provisions which make the decisions based upon summaries of case law extremely difficult to be reformed $^{42}$. Here one takes a look at some of these precedents, a result of more than 20 years of existence of the Court.

Summary of case law 58, of 1992, establishes that "once a forced tax collection is filed, the subsequent change of domicile of the debtor does not deprive the court of its jurisdiction". Such reasoning, which was not directly expressed in legislation, reflects an already mentioned practical aspect of forced tax collections: the difficulty to perform in a timely manner clerical tasks necessary to summon the debtor and to seize his assets. As it usually takes a significant span of time, the Court decided that the delay in the performance of acts of this nature, even if the debtor would have changed his domicile, would not be relevant to jurisdiction.

Summary of case law 112 rules over the suspension of the enforceability of tax liabilities, much to the complement of Article 151 of the National Tax Code. Article 151, II, reads that a deposit of the total amount of the debt should have the effect of suspending its enforceability, but the rule is not clear as to whether other forms of payment (that is to say, not in cash) have the same effect, neither as to whether the deposit of a partial amount could partially suspend the enforceability of the liability. In this vein, precedent 112 states that "the deposit could only suspend the enforceability of a tax liability if it covers the charges entirely and if it is done in cash".

Summary of case law 121 determines that "in forced tax collections, the debtor shall be notified, personally, of the day and time of the judicial sale". This rule lays down, therefore, the procedure to be observed in judicial sales, when the activities carried out by the government's lawyer result in asset freezing. The Court seems to note in such a situation the gravity which could justify an exceptional act in the course of any forced tax collection. Normally, only lawyers in a judicial

to a single case heard by the court, but rather a general guideline drawn by the court itself from its understanding expressed in different individual cases under similar circumstances. In Brazil, usually one speaks only of "súmula" followed by a number to refer to said guidelines.

42 Brazil. Code of Civil Procedure. Articles 517, paragraph 1, 543-C and 557 
procedure would need to be notified regarding the acts produced and to be produced within the process (Articles 39, I and 234 of the Code of Procedure). Meanwhile, here the Court said one is to give notice also to the interested party.

Concerns with judicial sales also led the Court to summary of case law 128, in 1995. It is laid down that "in forced tax collections there shall be a second attempt of judicial sale, if during the first attempt there was no bidding higher than that formerly appraised". Indirectly, the precedent makes reference to the proceeding of appraisal of the asset to be sold (Article 13 of Federal Law No. 6,830), which is carried out by a public agent subordinated to the structure of the Judiciary and which serves as parameters to repayment of the debt.

In 1996, by way of summary of case law 153, the Court decided upon an important issue concerning the dynamics of forced tax collections and of motions to stay execution. Article 16 of Federal Law No. 6,830, the main rule on the matter, does not provide for the necessity of the government paying lawyer's fee if it abandons the lawsuit against the debtor after a motion to stay had been already filed. In filling that gap, summary of case law 153 also comes to the complement of Article 26 of Federal Law No. 6,830, which states that in regular forced tax collections - not those in which there has been a motion to stay execution, governed by summary of case law $153-$, if the certificate of an overdue tax liability is cancelled, the case is to be dismissed and the parties are to bear no costs of loss of suit.

The Court decided, in 1997, that "the intervention of the Prosecution Office is unnecessary in forced tax collections". The Brazilian Constitution states that the Prosecution Office carries out an essential function in the justice system, as it is responsible for defending the legal order, the democratic regime and of the social and individual unwaivable rights (article 127). The court clarified that for the regular course of forced tax collections it is not necessary that members of the Prosecution Office be notified. Hence, these officials do not have to take a stand regarding tax charges, nor regarding procedural acts carried through in order to locate the debtor and his assets.

Summary of case law 409 brings about one specific feature of two more general concepts: peremption and limitation. One thinks of peremption when considering the time elapsed between the time the taxable event occurred and the time of assessment. Limitation, on the other hand, considers the time elapsed between the time the administrative procedure of assessment is finished and the time the forced tax collection is filed. Articles 173 and 174 of the National Tax Code provide, respectively, a period of five years. What summary of case law 409 is concerned about is the way a debate over the issue of limitation may come to the fore in forced tax collections. It reads that 
a judge may decide on the matter ex officio (Article 219, paragraph 5, of the Code of Civil Procedure), as opposed to the view that the debtor should expressly raise it in his challenge.

More recently, in 2010, summary of case law 435 introduced a rule of great significance to companies and persons in management positions. To fully understand that, some general observations on Brazilian tax law might come in handy here. Companies should abide by a set of ancillary obligations established by tax authorities in order to facilitate monitoring and collection of taxes (Article 113, paragraph 2, of the National Tax Code). Summary of case law 435 puts into force precisely a consequence for defaulting one of these ancillary obligations, in regard to which there was no consensus in case law: the obligation of informing tax authorities of any change in tax domicile. Concisely, if the corporation fails to comply with this obligation, its managers may become liable for tax-related debts. Such a scenario often happens in forced tax collections when a process server attempts to summon the company in the address it had previously informed to tax authorities, but which it no longer occupies. Summary of case law 435 considers this to be an illegal dissolution and consequently a violation of law, as per Article 135, III, of the National Tax Code.

\section{CONCLUSION}

This study attempted to describe the main features of forced tax collections in Brazil. After thirty-four years in force, however, there seems to be no indication that Federal Law No. 6,830 might soon be replaced. While one waits for a sudden congressional move on Bill No. 5,090/2009, forced tax collections will still be abundant and exclusively a matter handled by courts. It comes as no surprise, though, that this remedy hardly delivers what it promises to the government, whilst it still unnerves taxpayers and judges. Sometimes it takes years just to get passed over the administrative discussion of the assessment made by the monitoring tax authorities. Having to wait for another long period just to summon the debtor - and hopefully find his assets - should be not only frustrating, but also budget threatening. For those taxpayers intending to actually challenge what they consider to be in excess of the law, Federal Law No. 6,830 offers little flexibility in terms of collateralization and burden of proof rules. In the vortex of such a battlefield, courts find themselves having to deal with quite a number of cases, and a gaping legislation too. When thinking about forced tax collections in Brazil, indeed, one is reminded of an Oscar Wilde character, who had no enemies, but was intensely disliked by his friends. 


\section{REFERENCES}

\section{BOOKS:}

CAIS, Cleide Previtalli. O Processo Tributário. $5^{\text {th }}$ ed. rev. e ampl. São Paulo: Ed. Revista dos Tribunais, 2007.

CARRAZZA, Roque Antônio, ICMS, $12^{\text {th }}$ ed. São Paulo: Malheiros, 2007 CARVALHO, Paulo de Barros. Curso de Direito Tributário. São Paulo, 20a ed. rev. São Paulo: Saraiva, 2008.

MEIRELLES, Hely Lopes. Mandado de Segurança. 30a ed. São Paulo: Malheiros, 2007.

\section{CASE-LAW:}

Ação Direta de Inconstitucionalidade $n^{\circ} 3.952$.

AgRg no Ag 551.068/RJ, Rel. Ministro HUMBERTO MARTINS, SEGUNDA TURMA, julgado em 23/09/2008, DJe 23/10/2008 AgRg no MS 11.084/DF, Rel. Ministro JOSÉ DELGADO, PRIMEIRA SEÇAO, julgado em 26/04/2006, DJ 22/05/2006.

AgRg no REsp 1104543/RJ, Rel. Ministro BENEDITO GONÇALVES, PRIMEIRA TURMA, julgado em 04/05/2010, DJe 10/05/2010 AgRg no REsp 1205993/SP, Rel. Ministro BENEDITO GONÇALVES, PRIMEIRA TURMA, julgado em 26/10/2010, DJe 05/11/2010 EDcl no AgRg no REsp 1315220/MG, Rel. Ministro ARNALDO ESTEVES LIMA, PRIMEIRA TURMA, julgado em 24/04/2014, DJe 08/05/2014.

REsp 1205393/RJ, Rel. Ministro MAURO CAMPBELL MARQUES, SEGUNDA TURMA, julgado em 09/04/2013, DJe 16/04/2013.

REsp 1325709/RJ, Rel. Ministro NAPOLEÃO NUNES MAIA FILHO, PRIMEIRA TURMA, julgado em 24/04/2014, DJe 20/05/2014.

REsp 191.426/CE, Rel. Ministro HUMBERTO GOMES DE BARROS, PRIMEIRA TURMA, julgado em 19/08/1999, DJ 27/09/1999.

REsp 228.324/RS, Rel. Ministro JOÃO OTÁVIO DE NORONHA, SEGUNDA TURMA, julgado em 12/05/2005, DJ 01/07/2005, p. 458.

REsp 964151/PR, Rel. Ministro JOSÉ DELGADO, PRIMEIRA TURMA, julgado em 22/04/2008, DJe 21/05/2008).

\section{LEGISLATION:}

Code of Civil Procedure, 1973.

Constitution of the Federative Republic of Brazil, Constitutional text of 5 October 1988. 
Federal Law No. 6,830.

Federal Law No. 12,767.

National Tax Code, 1966.

\section{OFFICIAL DOCUMENTS:}

IPEA, Nota Técnica. Custo e tempo do processo de execução fiscal promovido pela Procuradoria-Geral da Fazenda Nacional. (http:// www.ipea.gov.br/agencia/images/stories/PDFs/nota_tecnica/111230_ notatecnicadiest1.pdf)

Martins, Vinícius. A nova execução fiscal, (http://jus.com.br/ artigos/14350/a-nova-execucao-fiscal)

Nascimento, Márgara. Execução fiscal: administrativa ou judicial?, (http:// ambitojuridico.com.br/site/?n_link=revista_artigos_leitura\&artigo_ $\mathrm{id}=13327$ \&revista_caderno $=26$ )

\section{WEBSITES:}

Câmara dos Deputados www.camara.gov.br

Contas Abertas www.contasabertas.com.br

Portal CNJ www.cnj.jus.br

Supremo Tribunal Federal www.stf.jus.br.

Valor Econômico www.valor.com.br 